\title{
MALAYSIAN HERBS IN SKIN AGING AND HYPERPIGMENTATION
}

\author{
TUAN NADRAH NAIM TUAN ISMAIL ${ }^{1 *}$, WAN NAZATUL SHIMA SHAHIDAN ${ }^{1}$ and \\ KANNAN THIRUMULU PONNURAJ ${ }^{1,2}$ \\ ${ }^{1}$ School of Dental Sciences, Universiti Sains Malaysia, \\ 16150 Kubang Kerian, Kelantan, Malaysia \\ ${ }^{2}$ Human Genome Centre, School of Medical Sciences, Universiti Sains Malaysia, \\ 16150 Kubang Kerian, Kelantan, Malaysia \\ *E-mail: tnadrah@usm.my
}

Accepted 7 March 2021, Published online 30 March 2021

\begin{abstract}
In the beauty and wellness industries, the association between herbs, skin aging, hyperpigmentation, and cosmeceuticals is gaining significance. The process of skin aging occurs in the epidermal and dermal layers and is primarily associated with the deterioration of the extracellular matrix (ECM). Deterioration of ECM can be due to increased matrix metalloproteinases (MMPs) or decreased transforming growth factor- $\beta$ (TGF- $\beta$ ). Along with some pigment defects such as hypo or hyperpigmentation, this process can cause skin wrinkles, roughness, and dryness. There is a need to slow down the ECM degradation and inhibition of melanin formation. Herbs have a high potential due to their various biologically active compounds. Malaysia is one of the countries rich in tropical rainforests with its traditional medicinal herbs. However, the use of Malaysian herbs in skin aging and hyperpigmentation is still limited. Thus, this review focuses on selected Malaysian herbs that are traditionally used for various purposes and have potential as anti-aging and anti-hyperpigmentation properties. The information contained in the present review indicates that selected Malaysian herbs can be used in the treatment of skin aging and hyperpigmentation and will assist the cosmetics sectors in the development of herbal anti-aging and antihyperpigmentation formulations.
\end{abstract}

Key words: Aging, herbs, hyperpigmentation, Malaysia

\section{INTRODUCTION}

As the famous quote goes 'Age is an issue of mind over matter. If you don't mind, it doesn't matter. However, having said that, aging is an inevitable process that all living organisms have to undergo. The percentage of the population 60 years and above has increased over the years. Currently, $11 \%$ of the world's population is over 60 years of age, with estimates of nearly $22 \%$ by 2050 , particularly in developing countries (Newgard \& Sharpless, 2013). The factors that drive the population aging are improved survival of people at older and younger ages (World Health Organization, 2015). World Health Organization (2015) stated that the underlying changes which tend to occur in all humans to some degree as they age include movement, sensory and cognitive functions, sexuality, immune and skin functions. With age, skin experiences progressive declines resulting from damage caused by physio-

\footnotetext{
* To whom correspondence should be addressed.
}

logical processes, environmental factors, particularly sun exposure, and lifestyle that have been shown to promote the development of reactive oxygen species (ROS) and produce oxidative stress (Naidoo \& BirchMachin, 2017).

Of late, the growth of herbal cosmetic products is showing an uptrend due to the current demand and focus on natural products. In recent years, some manufacturers often label their products associated with plant-based or organic ingredients as natural products contain certain amounts of ingredients based on plants and/or organically grown (Belova \& Eilks, 2015). World Health Organization has stated that about two-thirds and $50-80 \%$ of the population of developed and developing countries use traditional and complementary medicine (TCAM), respectively (Siti et al., 2009). A study by the Ministry of Health found that herbal therapy was the main type of TCAM modality used by the Malaysian populations (Siti et al., 2009). However, there is still a lack of scientific information about the role and application of Malaysian herbs in conditions relating 
to skin aging and hyperpigmentation. Traditional herbs provide fascinating and largely unexplored sources of possible new cosmetic and medicinal products. The trade values of herbal imports and exports in Malaysia recorded in 2014 amounted to US\$ 2077 million and US\$ 441.7 million, respectively with an annual growth rate between 8 to $15 \%$ (Zakaria, 2015). The current review article is based on certain salient Malaysian herbs claimed and some proven to have been used in the treatment of skin aging and hyperpigmentation.

By searching some databases such as Google Scholar, Medline, Scopus, PubMed, and PLoS, this review study was prepared using the keywords anti-aging, hyperpigmentation, antioxidant, phytochemical characteristics, Curcuma longa, Andrographis paniculata, Ficus deltoidea, Cinnamon cassia, Clinacanthus nutans, Centella asiatica, and Morinda citrifolia. Among these, five herbs that have been identified and proposed for commercialization in the industry by National Key Economic Area include Clinacanthus nutans, Andrographis paniculata, Ficus deltoidea, Centella asiatica, and Morinda citrifolia (Zakaria, 2016).

\section{Skin aging}

Skin aging can be categorized into intrinsic and extrinsic aging. Due to telomere shortening, mitochondrial DNA mutations, oxidative stress, genetic mutations, and strong hormonal changes, intrinsic skin aging can be categorized as normal aging. (Kohl et al., 2011). While extrinsic aging is mainly caused by the exposure of the skin to ultraviolet radiation. Other causes of extrinsic aging are smoking, pollution, and poor diet (Kohl et al., 2011). Aging causes wrinkling, roughness, and dryness of the skin along with certain pigment abnormalities such as hypo or hyperpigmentation (Tobin, 2017).

Molecular pathways show similarities between intrinsic and extrinsic skin aging. Both types of skin aging cause reactive oxygen species, primarily arising from oxidative cell metabolism (Kohl et al., 2011). The process of skin aging occurs in the epidermal and dermal layers and is primarily associated with the deterioration of the extracellular matrix (ECM) (Cole et al., 2018). Matrix metalloproteinases (MMPs) are the enzymes involved in ECM degradation. Due to the impact of ECM degradation by MMPs, the skin loses its tensile strength. These MMPs can be subdivided into several classes, such as collagenase (MMP-1), gelatinase (MMP-2 and MMP-9), stromelysin (MMP3 and MMP-11), membrane-associated (MMP-17), and recently described MMP-27, respectively (Quan \& Fisher, 2015).

In ECM biosynthesis, transforming growth factor- $\beta$ (TGF- $\beta$ ) plays a core function. It is a cytokine that promotes collagen production in human dermal fibroblasts (Quan \& Fisher, 2015). Natural products that inhibit the MMPs and stimulate the TGF- $\beta$ production have the potential as an anti-aging agent. Natural products that have antioxidant properties also have the potential to be an anti-photoaging agent since a primary cause of the generation of reactive oxygen species (ROS) in the skin is ultraviolet irradiation.

\section{Hyperpigmentation}

Hyperpigmentation is triggered by UV irradiation, female sex hormones, and inflammatory processes with a genetic predisposition (Lee, 2015). Most of the commercially available treatments for hyperpigmentation target tyrosinase. Tyrosinase is a ratelimiting enzyme that transforms tyrosine to melanin (Lee et al., 2016). As skin-lighting agents, tyrosine inhibitors thus play an important role. Other than tyrosinase, oxidative stress also stimulates melanogenesis. Oxidative stress can be triggered by extrinsic and intrinsic factors. Extrinsic factors such as ultraviolet radiation and visible light and intrinsic factors like paracrine regulation of melanocytes influence their response to ultraviolet radiation. A recent study has shown that the antioxidant plays a role as a skin lightening agent as it can downregulate ultraviolet radiation and visiblelight-induced hyperpigmentation (Nahhas et al., 2019). In this review, general information about the traditional uses and the potential as an anti-aging and anti-hyperpigmentation of identified Malaysian herbs are reported. The mechanism involved in skin aging and hyperpigmentation is depicted in Figure 1.

\section{Natural herbs}

Herbal medicine usage is not only popular among individuals but also primary health care providers in developing countries. The World Health Organization reported that 70 to $80 \%$ of the world population relies mainly on herbal sources for their primary medicines (World Health Organization, 2000). Nowadays, the use of herbs is not limited to health or to treat diseases. Cosmetic formulations based on herbs are on the rise as more consumers demand healthier options. Continuous application of synthetic compounds on the skin causes many adverse effects such as skin irritation, allergy, discoloration, rashes along with skin cancer. This review article aims to explore Malaysian herbs that have potential as antiaging and anti-hyperpigmentation properties.

\section{Labisia pumila}

Labisia pumila (L. pumila), locally known as Kacip Fatimah, has historically been used by Malay women before and after delivery for generations. A decoction of water from the roots of the entire plant of L. pumila is often granted to women who are 


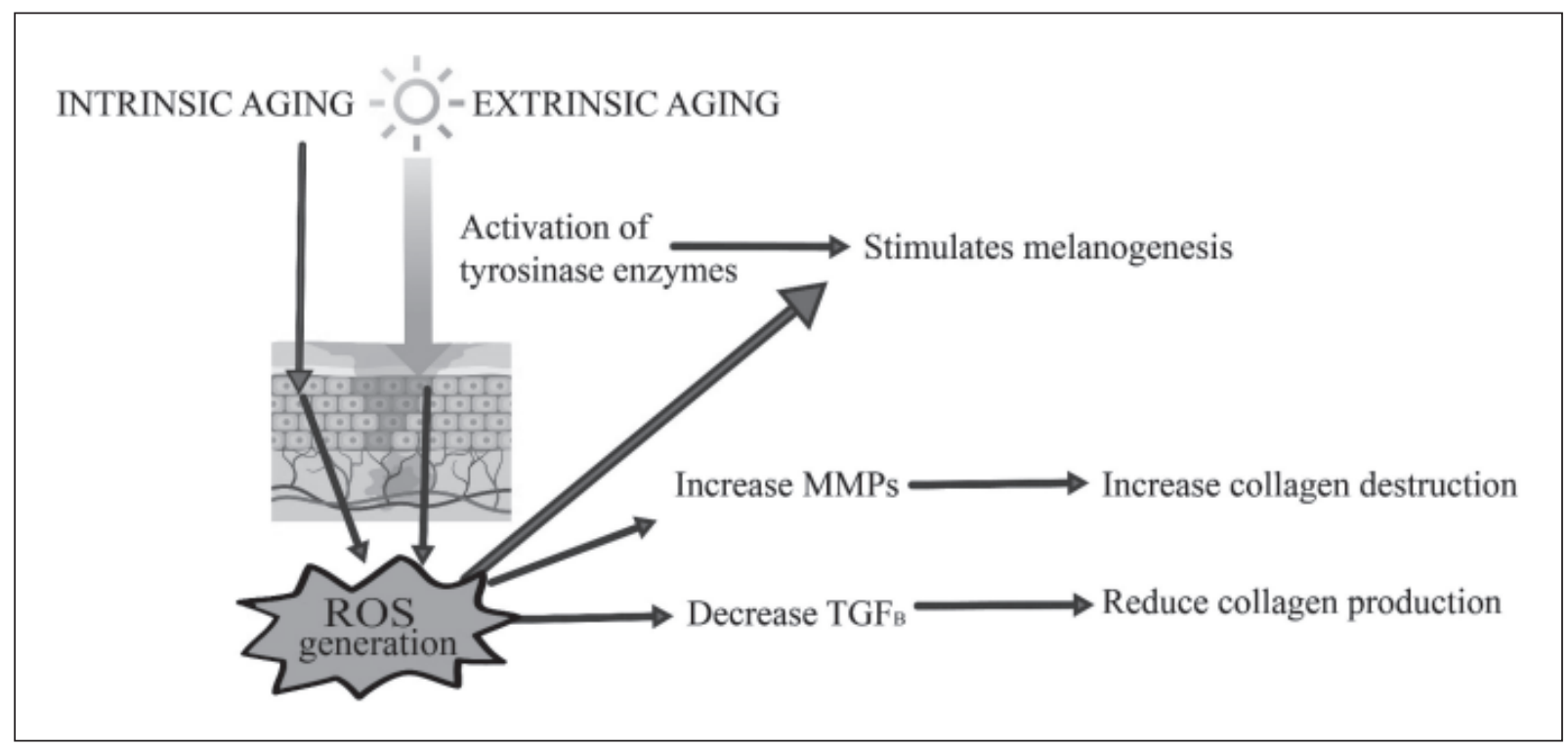

Fig. 1. Mechanism involved in skin aging and hyperpigmentation.

pregnant from one and two months before birth, as this is believed to stimulate and intensify labor. Also, it was mentioned that L. pumila can be used after childbirth as it improves uterine contraction, reduces fertility, and restores body strength (Shahrim et al., 2006). Up to now, it has been taken by local individuals to maintain a healthy female reproductive system, treat menstrual abnormalities, and improve sexual function. Other common plant uses include dysentery treatment, rheumatism, gonorrhea, and removal of gas from the body (Burkill, 1935). A recent study has shown that $L$. pumila has an antiphotoaging effect on the UVB-irradiated skin cells (Choi et al., 2010). The authors found that the water extract of $L$. pumila significantly had an antioxidant effect, decreased the TNF- $\alpha$ level and UVB-induced COX-2 expression, increased pro-collagen type 1 expression, and decreased MMP-1 as well as MMP9 expression. Although no studies have reported the active compound responsible for the anti-aging properties, previous studies have shown L. pumila to be rich in phenolic compounds including phenolic acids and flavonoids (Chua et al., 2011; Karimi \& Jaafar, 2011). The anti-aging property might be due to the role of phenolic compounds participating in the antioxidant mechanisms such as scavenging the reactive oxygen species and thus preventing the cells from undergoing oxidative stress. A study by Karimi and Jaafar (2011) found that the leaves of plants showed higher antioxidant activities compared to the roots and stems. The study on its safety in the cosmetic application is still lacking.

\section{Curcuma longa $\mathrm{L}$.}

Traditionally in Malaysia, a decoction of the Curcuma longa L. (C. longa L.) or commonly known as Kunyit by local people is given to increase blood circulation, relieve abdominal discomfort, remove wind, alleviate muscle and joint pain, and restore body strength (Jamal et al., 2011). Besides that, its other medicinal uses include anthelmintic (Bazh \& ElBahy, 2013), anti-hyperglycemic (Ng \& See et al., 2019), neuroprotective (Issuriya et al., 2014), anticancer (Vallianou et al., 2015), and antihyperlipidaemic (Maithilikarpagaselvi et al., 2016) effects. A recent study showed that $C$. longa L. had anti-aging properties in vitro and in vivo (Muta et al., 2018). The authors found that an extract of rhizomes of $C$. longa L. showed an inhibitory effect on gelatinase activity. Furthermore, topical application of a cream containing $C$. longa L. extract improved the elasticity of the facial skin substantially and inhibited the activity of gelatinase in human facial skin. A study of $C$. longa L showed that its rhizome is rich in curcuminoids, phenolic acids, flavonoids, and iron (Pal et al., 2020). Curcuminoids are known to have anti-wrinkle properties by inhibiting induction of UV-B in keratinocytes and induction of TNF- $\alpha$ in fibroblasts (Jang et al., 2012). The authors found that curcuminoids including desmethoxycurcumin and bisdemethoxycurcumin inhibited UV-B-induced NF- $\mathrm{KB}$ activation in keratinocytes and reduced the expression of MMP-1 in both keratinocytes and fibroblasts. On top of that, $C$. longa $\mathrm{L}$ showed anti-tyrosinase activity (Tamfu et al., 2020), thus having the potential as a skin lightening agent. However, it may cause an adverse effect. Curcumin, the main ingredient in turmeric has been reported to cause contact dermatitis (Chaudhari et al., 2015). Thus, people who have hypersensitivity to turmeric should avoid this herb. 
Table 1. Malaysian herbs and their bioactive compounds and mechanisms of anti-aging and anti-hyperpigmentation properties

\begin{tabular}{|c|c|c|c|c|}
\hline Species & Local name & Bioactive compounds & $\begin{array}{l}\text { Mechanism of anti-aging } \\
\text { property }\end{array}$ & $\begin{array}{l}\text { Mechanism of anti- } \\
\text { hyperpigmentation } \\
\text { property }\end{array}$ \\
\hline $\begin{array}{l}\text { Labisia } \\
\text { pumila }\end{array}$ & $\begin{array}{l}\text { Kacip } \\
\text { Fatimah }\end{array}$ & $\begin{array}{l}\text { - phenolic acids } \\
\text { - flavonoids }\end{array}$ & $\begin{array}{l}\text { - increase pro-collagen } \\
\text { type } 1 \text { expression. } \\
\text { - decrease MMP-1 as well } \\
\text { as MMP-9 expression. } \\
\text { - scavenging the reactive } \\
\text { oxygen species }\end{array}$ & \\
\hline Curcuma longa L. & Kunyit & $\begin{array}{l}\text { - curcuminoids } \\
\text { (desmethoxycurcumin } \\
\text { and } \\
\text { bisdemethoxycurcumin) } \\
\text { - phenolic acids } \\
\text { - flavonoids }\end{array}$ & $\begin{array}{l}\text { - reduce the expression } \\
\text { of MMP-1 }\end{array}$ & $\begin{array}{l}\text { - anti-tyrosinase } \\
\text { activity }\end{array}$ \\
\hline Ficus deltoidea & Mas Cotek & $\begin{array}{l}\text { - flavan-3-ol monomers and } \\
\text { proanthocyanidins }\end{array}$ & - antioxidant & $\begin{array}{l}\text { - anti-tyrosinase } \\
\text { activity }\end{array}$ \\
\hline $\begin{array}{l}\text { Clinacanthus } \\
\text { nutans }\end{array}$ & Belalai Gajah & $\begin{array}{l}\text { - terpenoids } \\
\text { - phenolics } \\
\text { - benzenoids } \\
\text { - cerebrosides } \\
\text { - glycoglycerolipids } \\
\text { - glycosylglycerides } \\
\text { fatty acids } \\
\text { - chlorophyll } \\
\text { derivatives } \\
\text { - phytosterols } \\
\text { - sulfur-containing } \\
\text { glucosides }\end{array}$ & $\begin{array}{l}\text { - increase collagen } \\
\text { content in the skin of } \\
\text { the volunteers (in vivo } \\
\text { study) }\end{array}$ & $\begin{array}{l}\text { - anti-tyrosinase } \\
\text { activity }\end{array}$ \\
\hline $\begin{array}{l}\text { Andrographis } \\
\text { paniculata }\end{array}$ & $\begin{array}{l}\text { Hempedu } \\
\text { Bumi }\end{array}$ & $\begin{array}{l}\text { - diterpenoids (14- } \\
\text { deoxyandrographolide } \\
\text { and andrographolide) }\end{array}$ & $\begin{array}{l}\text { - increased Type } 1 \\
\text { collagen production. } \\
\text { - decreased ROS } \\
\text { production } \\
\text { - enhanced skin } \\
\text { hydration, sagging, } \\
\text { wrinkling, and dermal } \\
\text { density (in vivo study) }\end{array}$ & $\begin{array}{l}\text { - decreased ROS } \\
\text { production }\end{array}$ \\
\hline Cinnamon cassia & Kayu Manis & - cinnamaldehyde & $\begin{array}{l}\text { - activation of insulin-like } \\
\text { growth factor-I (IGF-I) } \\
\text { signaling in human } \\
\text { dermal fibroblasts }\end{array}$ & $\begin{array}{l}\text { - anti-tyrosinase } \\
\text { activity }\end{array}$ \\
\hline Centella asiatica & Pegaga & $\begin{array}{l}\text { - asiaticoside } \\
\text { - asiatic acid } \\
\text { - madecassic acid }\end{array}$ & $\begin{array}{l}\text { - inhibitory activity against } \\
\text { hyaluronidase, elastase, } \\
\text { and MMP-1 enzyme }\end{array}$ & $\begin{array}{l}\text { - anti-tyrosinase } \\
\text { activity }\end{array}$ \\
\hline Morinda citrifolia & Mengkudu & $\begin{array}{l}-3,3^{\prime}- \\
\text { bisdemethylpinoresinol }\end{array}$ & - anti-elastase activity & $\begin{array}{l}\text { - anti-tyrosinase } \\
\text { activity }\end{array}$ \\
\hline
\end{tabular}

\section{Ficus deltoidea}

Ficus deltoidea ( $F$. deltoidea) or commonly known by Malaysian as Mas cotek is a Malay traditional medicine that is very popular due to its good medicinal properties. As a traditional medicine, it has been used to treat diseases like a wound, sores, rheumatism, diabetes mellitus and as an after-birth tonic (Bunawan et al., 2014). The $F$. deltoidea dried leaves have been consumed and sold as herbal tea and capsules among Malaysians throughout many years. The decoction of the leaves has been reported to possess antidiabetic, antiulcerogenic, antioxidant, anti-melanogenic, antiinflammatory, analgesic, and antihypertensive properties (Ramamurthy et al., 2014). Another study showed that the water extract of $F$. deltoidea leaves had wound healing and antioxidant properties (Omar et al., 2011; Mustaffa et al., 2015). Ficus deltoidea has been reported to have a high content of phenolic acids and flavonoids (Soib et al., 2019). The main 
phenolic compounds attributed to its antioxidant activity were flavan-3-ol monomers and proanthocyanidins (Omar et al., 2011). There is no study on its anti-aging property has been reported. However, the antioxidant properties of $F$. deltoidea could play a role in anti-aging.

Ficus deltoidea extract has a significant antimelanogenic effect exerted by direct inhibition of the activity of the tyrosinase enzyme and by downregulation of the expression of genes involved in the pathways of melanogenesis (Oh et al., 2011). no study has reported the active compound responsible for its anti-hyperpigmentation property. However, its scavenging ROS effect due to the high content of phenolic acids and flavanoids in $F$. deltoidea may inhibit melanogenesis production. Similar to L. pumila, there is a dearth of information on its safety to topical application.

\section{Clinacanthus nutans}

In Malaysia, Clinacanthus nutans (C. nutans) is called as Belalai gajah. This herb is consumed as herbal tea to treat diseases such as skin rashes, mosquitoes and snake bites, Herpes simplex virus lesions, diabetes, and gout (Alam et al., 2016). A study showed that $C$. nutans had potential as an anti-hyperpigmentation agent. Its extract, especially its seeds inhibited the tyrosinase enzyme (Thongmuang \& Sudjaroen, 2013). Interestingly, another study showed that $C$. nutans had the potential as an anti-aging agent. The in vivo study showed that with the application of $C$. nutans nanoemulsion, the collagen content in the skin of the volunteers increased significantly (Che Sulaiman et al., 2017). Similar to L. pumila, there are no studies that have reported the active compound responsible for its anti-aging and anti-hyperpigmentation properties, however, $C$. nutans has been reported to have various bioactive compounds including terpenoids, phenolics, benzenoids, cerebrosides, glycoglycerolipids, glycosylglycerides fatty acids, chlorophyll derivatives, phytosterols, and sulfurcontaining glucosides (Kamarudin et al., 2017). The synergistic effect of these compounds contributes to their diverse bioactivities. The safety information of C. nutans on the topical application is also lacking.

\section{Andrographis paniculata}

Andrographis paniculata (A. paniculata) which is also known as Hempedu bumi by local people is commonly used as a health tonic for liver and cardiovascular health and the treatment of common cold, diarrhea, and fever due to various infectious causes. It is also used to boost sexual dysfunction and act as a contraceptive (Hossain et al., 2014). A recent study showed that $A$. paniculata extract had in vitro and in vivo anti-aging properties (You et al., 2015) and found that $A$. paniculata extract increased the Type 1 collagen production in normal human fibroblasts. They have also reported that $A$. paniculata extract has greatly enhanced skin hydration, sagging, wrinkling, and dermal density. Andrographis paniculata contains diterpenoids called andrographolide responsible for a wide range of biological activities. A recent study showed that methanolic extract of $A$. paniculata and its bioactive diterpenoids include 14-deoxyandrographolide and andrographolide decreased ROS production in dermal fibroblasts and decreased an inflammation marker, IL-6 and TNF- $\alpha$ expression (Mussard et al., 2020). Interestingly, the authors found that $A$. paniculata and its bioactive were non-toxic to keratinocytes.

\section{Cinnamon cassia}

The stem bark of Cinnamon cassia ( $C$. cassia) or called Kayu manis by local people is commonly used as a flavoring agent in various Malaysian cooking. However, the use of $C$. cassia as food should be used with precaution since one of the ingredients in C. cassia is coumarin. It is forbidden to use coumarin in food, but the coumarins contained naturally are not (Wang et al., 2013). A previous study of $C$. cassia essential oil showed its main component as cinnamaldehyde, which has strong anti-tyrosinase and anti-melanogenic activities (Chou et al., 2013). Another study showed that cinnamaldehyde promotes type I collagen biosynthesis via activation of insulin-like growth factor-I (IGF-I) signaling in human dermal fibroblasts (Takasao et al., 2012). Takasao et al. (2012) showed in an IGF-I-independent manner, cinnamaldehyde substantially increased the phosphorylation levels of the IGF-I receptor and its downstream signaling molecules, such as insulin receptor substrate- 1 and Erk1/2. Although cinnamaldehyde has anti-aging and anti-melanogenic properties, few cases of intraoral allergic contact dermatitis to cinnamon flavoring agents have been reported (Isaac-Renton et al., 2015). Thus, the use of C. cassia in the topical application should be avoided in certain patients.

\section{Centella asiatica}

Centella asiatica ( $C$. asiatica) or commonly known as Pegaga by Malaysian is consumed in raw form by Malays as side dishes with rice ( $\mathrm{Ng}$ et al., 2020a). The plant is beneficial for rheumatism, rising brain capacity by increasing vitality, reducing the level of blood sugar, skin disease, improved circulation, and arthritis. Previous studies showed that $C$. asiatica has both anti-aging and antihyperpigmentation properties. The study of methanol extract of $C$. asiatica and its fractions showed that both extracts and its fractions had potent inhibitory activity against hyaluronidase, elastase, and MMP1 enzyme (Nema et al., 2013). The authors found that 
methanol extract of $C$. asiatica showed the highest hyaluronidase inhibitory and elastase inhibitory activities, while the aqueous fraction showed the highest MMP-1 inhibitory activity. On top of that, C. asiatica was found as a potent antioxidant $(\mathrm{Ng}$ et al., 2020b). The potential of C. asiatica in antiaging could be due to its scavenging ROS effect.

On the other hand, a study on a titrated extract of $C$. asiatica (TECA) containing asiaticoside, asiatic acid, and madecassic acid showed their potential as an anti-hyperpigmentation agent. TECA inhibited melanogenesis via inhibiting tyrosinase mRNA expression (Kwon et al., 2014). Although C. asiatica is one of the herbal medicines that have cosmetic potential, some precautions should be undertaken because this herb has been reported to cause contact dermatitis in some cases (Garijo, 1996).

\section{Morinda citrifolia}

Morinda citrifolia (M. citrifolia) also known as Mengkudu is a tiny evergreen tree. It is native to Southeast Asia and is found in Southeast Asia such as Malaysia, Thailand, Philippines, Indonesia, and some regions in Africa include Samoa, Tonga, and Cuba (Mathivanan et al., 2005). The leaves have a length of 8 or more inches and an oval shape. The diameter of the fruit is 3 to 4 inches with a warty, pitted surface. It seems to have been highly medicinally valued in the tropics. All parts of $M$. citrifolia such as fruit, leaf, bark, and root have been reported to possess medicinal values as antidiabetic, anticancer, and in reducing hypertension (ChanBlanco et al., 2006). A previous study showed the potential of $M$. citrifolia $\mathrm{L}$ as an anti-aging and antihyperpigmentation agent (Masuda et al., 2009). The authors found that ethanol extract of $M$. citrifolia seeds had anti-elastase and anti-tyrosinase activities. The other study found that one of the constituents of ethanol extract of $M$. citrifolia seeds which is 3,32 -bisdemethylpinoresinol had MMP-1 inhibitory activity in UVA-irradiated normal human dermal fibroblasts by down-regulation of mitogenactivated protein kinases phosphorylation without cytotoxic effect at $0.3 \mathrm{iM}$ concentration (Masuda et al., 2012). To date, there are no data available on the topical use of $M$. citrifolia in contact dermatitis. Interestingly, a recent study has shown that oral administration of fermented $M$. citrifolia has the potential to treat atopic dermatitis (Kim et al., 2020).

\section{CONCLUSION}

This review article highlights the anti-aging and antihyperpigmentation properties of Malaysian herbs. These herbs have been used as medicinal plants over the past few decades and of late, have been found to have cosmetic potential. The information derived from this review is hoped will assist the cosmetic scientists and other researchers involved in the development of herbal anti-aging formulations using Malaysian herbs in the reduction of wrinkles, skin laxity, and hyperpigmentation. The use of these Malaysian herbs would pave the way in producing more efficient, low toxic, and cost-effective products compared to other synthetic anti-aging formulations that can be exploited in the future. However, the safety of some herbs including L. pumila, $F$. deltoidea, $C$. nutans, and A. paniculata on the topical application is still lacking. Thus, their safety of application is crucial to be established.

\section{REFERENCES}

Alam, A., Ferdosh, S., Ghafoor, K., Hakim, A., Juraimi, A.S., Khatib, A. \& Sarker, Z.I. 2016. Clinacanthus nutans: A review of the medicinal uses, pharmacology and phytochemistry. Asian Pacific Journal of Tropical Medicine, 9(4): 402409.

Bazh, E.K. \& El-Bahy, N.M. 2013. In vitro and in vivo screening of anthelmintic activity of ginger and curcumin on Ascaridia galli. Parasitology Research, 112(11): 3679-3686.

Belova, N. \& Eilks, I. 2015. Learning with and about advertising in chemistry education with a lesson plan on natural cosmetics - a case study. Chemistry Education Research and Practice, 16(3): 578-588.

Bunawan, H., Amin, N.M., Bunawan, S.N., Baharum, S.N. \& Mohd Noor, N. 2014. Ficus deltoidea Jack: a review on its phytochemical and pharmacological importance. Evidence-Based Complementary and Alternative Medicine, 2014: 1-8.

Burkill, I.H. 1935. A dictionary of the economic products of the Malay Peninsula. Volume II (IZ). Crown Agents for the Colonies, London.

Chan-Blanco, Y., Vaillant, F., Perez, A.M., Reynes, M., Brillouet, J.M. \& Brat, P. 2006. The noni fruit (Morinda citrifolia L.): A review of agricultural research, nutritional and therapeutic properties. Journal of Food Composition and Analysis, 19(6-7): 645-654.

Chaudhari, S.P., Tam, A.Y. \& Barr, J.A. 2015. Curcumin: A contact allergen. The Journal of Clinical and Aesthetic Dermatology, 8(11): 43.

Che Sulaiman, I.S., Basri, M., Fard Masoumi, H.R., Ashari, S.E., Basri, H. \& Ismail, M. 2017. Predicting the optimum compositions of a transdermal nanoemulsion system containing an extract of Clinacanthus nutans leaves (L.) for skin antiaging by artificial neural network model. Journal of Chemometrics, 31(7): e2894. 
Choi, H.K., Kim, D.H., Kim, J.W., Ngadiran, S., Sarmidi, M.R. \& Park, C.S. 2010. Labisia pumila extract protects skin cells from photoaging caused by UVB irradiation. Journal of Bioscience and Bioengineering, 109(3): 291-296.

Chou, S.T., Chang, W.L., Chang, C.T., Hsu, S.L., Lin, Y.C. \& Shih, Y. 2013. Cinnamomum cassia essential oil inhibits $\alpha$-MSH-induced melanin production and oxidative stress in murine B16 melanoma cells. International Journal of Molecular Sciences, 14(9): 19186-19201.

Chua, L.S., Latiff, N.A., Lee, S.Y., Lee, C.T., Sarmidi, M.R. \& Aziz, R.A. 2011. Flavonoids and phenolic acids from Labisia pumila (Kacip Fatimah). Food Chemistry, 127(3): 1186-1192.

Cole, M.A., Quan, T., Voorhees, J.J. \& Fisher, G.J. 2018. Extracellular matrix regulation of fibroblast function: redefining our perspective on skin aging. Journal of Cell Communication and Signaling, 12(1): 35-43.

Garijo, G. 1996. Allergic contact dermatitis due to Centella asiatica: A new case. Allergologia et Immunopathologia, 24(3):132-134.

Hossain, M., Urbi, Z., Sule, A. \& Rahman, K. 2014. Andrographis paniculata (Burm. f.) Wall. ex Nees: A review of ethnobotany, phytochemistry, and pharmacology. The Scientific World Journal, 2014: 1-28.

Isaac-Renton, M., Li, M.K. \& Parsons, L.M. 2015. Cinnamon spice and everything not nice: many features of intraoral allergy to cinnamic aldehyde. Dermatitis, 26(3): 116-121.

Issuriya, A., Kumarnsit, E., Wattanapiromsakul, C. \& Vongvatcharanon, U. 2014. Histological studies of neuroprotective effects of Curcuma longa Linn. on neuronal loss induced by dexamethasone treatment in the rat hippocampus. Acta Histochemica, 116(8): 1443-1453.

Jamal, J.A., Ghafar, Z.A. \& Husain, K. 2011. Medicinal plants used for postnatal care in Malay traditional medicine in the Peninsular Malaysia. Pharmacognosy Journal, 3(24): 15-24.

Jang, S., Chun, J., Shin, E.M., Kim, H. \& Kim, Y.S. 2012. Inhibitory effects of curcuminoids from Curcuma longa on matrix metalloproteinase-1 expression in keratinocytes and fibroblasts. Journal of Pharmaceutical Investigation, 42(1): 33-39.

Kamarudin, M.N.A., Sarker, M.M.R., Kadir, H.A. \& Ming, L.C. 2017. Ethnopharmacological uses, phytochemistry, biological activities, and therapeutic applications of Clinacanthus nutans (Burm. f.) Lindau: A comprehensive review. Journal of Ethnopharmacology, 206: 245-266.

Karimi, E. \& Jaafar, H.Z. 2011. HPLC and GC-MS determination of bioactive compounds in microwave obtained extracts of three varieties of
Labisia pumila Benth. Molecules, 16(8): 67916805.

Kim, S.H., Seong, G.S. \& Choung, S.Y. 2020. Fermented Morinda citrifolia (Noni) alleviates DNCB-induced atopic dermatitis in NC/Nga mice through modulating immune balance and skin barrier function. Nutrients, 12(1): 249.

Kohl, E., Steinbauer, J., Landthaler, M. \& Szeimies, R.M. 2011. Skin ageing. Journal of the European Academy of Dermatology and Venereology, 25(8): 873-884.

Kwon, K.J., Bae, S., Kim, K., An, I. S., Ahn, K.J., An, S. \& Cha, H.J. 2014. Asiaticoside, a component of Centella asiatica, inhibits melanogenesis in B16F10 mouse melanoma. Molecular Medicine Reports, 10(1): 503-507.

Lee, A.Y. 2015. Recent progress in melasma pathogenesis. Pigment Cell \& Melanoma Research, 28(6): 648-660.

Lee, S.Y., Baek, N. \& Nam, T.G. 2016. Natural, semisynthetic and synthetic tyrosinase inhibitors. Journal of Enzyme Inhibition and Medicinal Chemistry, 31(1): 1-13.

Maithilikarpagaselvi, N., Sridhar, M.G., Swaminathan, R.P., Sripradha, R. \& Badhe, B. 2016. Curcumin inhibits hyperlipidemia and hepatic fat accumulation in high-fructose-fed male Wistar rats. Pharmaceutical Biology, 54(12): 2857-2863.

Masuda, M., Itoh, K., Murata, K., Naruto, S., Uwaya, A., Isami, F. \& Matsuda, H. 2012. Inhibitory effects of Morinda citrifolia extract and its constituents on melanogenesis in murine B16 melanoma cells. Biological and Pharmaceutical Bulletin, 35(1): 78-83.

Masuda, M., Murata, K., Fukuhama, A., Naruto, S., Fujita, T., Uwaya, A., Isami, F. \& Matsuda, H. 2009. Inhibitory effects of constituents of Morinda citrifolia seeds on elastase and tyrosinase. Journal of Natural Medicines, 63(3): 267-273.

Mathivanan, N., Surendiran, G., Srinivasan, K., Sagadevan, E. \& Malarvizhi, K. 2005. Review on the current scenario of Noni research: Taxonomy, distribution, chemistry, medicinal and therapeutic values of Morinda citrifolia. International Journal of Noni Research, 1(1): 1-16.

Mussard, E., Jousselin, S., Cesaro, A., Legrain, B., Lespessailles, E., Esteve, E., Berteina-Raboin, S. \& Toumi, H. 2020. Andrographis paniculata and its bioactive diterpenoids against inflammation and oxidative stress in keratinocytes. Antioxidants, 9(6): 530.

Mustaffa, N.A.A.W., Hasham, R. \& Sarmidi, M.R. 2015. An in vitro study of wound healing activity of Ficus deltoidea leaf extract. Jurnal Teknologi, 77(3): 67-72. 
Muta, K., Inomata, S., Fukuhara, T., Nomura, J., Nishiyama, T., Tagawa, Y.-I. \& Amano, S. 2018. Inhibitory effect of the extract of rhizome of Curcuma longa $\mathrm{L}$ in gelatinase activity and its effect on human skin. Journal of Bioscience and Bioengineering, 125(3): 353-358.

Nahhas, A.F., Abdel Malek, Z.A., Kohli, I., Braunberger, T.L., Lim, H.W. \& Hamzavi, I.H. 2019. The potential role of antioxidants in mitigating skin hyperpigmentation resulting from ultraviolet and visible light induced oxidative stress. Photodermatology, Photoimmunology \& Photomedicine, 35(6): 420-428.

Naidoo, K. \& Birch-Machin, M.A. 2017. Oxidative stress and ageing: the influence of environmental pollution, sunlight and diet on skin. Cosmetics, 4(1): 4.

Nema, N.K., Maity, N., Sarkar, B.K. \& Mukherjee, P.K. 2013. Matrix metalloproteinase, hyaluronidase and elastase inhibitory potential of standardized extract of Centella asiatica. Pharmaceutical Biology, 51(9): 1182-1187.

Newgard, C.B. \& Sharpless, N.E. 2013. Coming of age: molecular drivers of aging and therapeutic opportunities. The Journal of Clinical Investigation, 123(3): 946-50.

Ng, Z.X., Samsuri, S.N. \& Yong, P.H. 2020a. The antioxidant index and chemometric analysis of tannin, flavonoid, and total phenolic extracted from medicinal plant foods with the solvents of different polarities. Journal of Food Processing and Preservation, 44: e14680.

Ng, Z.X. \& See, A.N. 2019. Effect of in vitro digestion on the total polyphenol and flavonoid, antioxidant activity and carbohydrate hydrolyzing enzymes inhibitory potential of selected functional plant based foods. Journal of Food Processing and Preservation, 43(4): e13903.

Ng, Z.X., Yong, P.H. \& Lim, S.Y. 2020b. Customized drying treatments increased the extraction of phytochemicals and antioxidant activity from economically viable medicinal plants. Industrial Crops and Products, 155: 112815.

Oh, M.J., Hamid, M.A., Ngadiran, S., Seo, Y.K., Sarmidi, M.R. \& Park, C.S. 2011. Ficus deltoidea (Mas cotek) extract exerted anti-melanogenic activity by preventing tyrosinase activity in vitro and by suppressing tyrosinase gene expression in B16F1 melanoma cells. Archives of Dermatological Research, 303(3): 161-170.

Omar, M.H., Mullen, W. \& Crozier, A. 2011. Identification of proanthocyanidin dimers and trimers, flavone C-glycosides, and antioxidants in Ficus deltoidea, a Malaysian herbal tea. Journal of Agricultural and Food Chemistry, 59(4): 1363-1369.
Pal, K., Chowdhury, S., Dutta, S.K., Chakraborty, S., Chakraborty, M., Pandit, G.K., Dutta, S., Paul, P.K., Choudhury, A. \& Majumder, B. 2020. Analysis of rhizome colour content, bioactive compound profiling and ex-situ conservation of turmeric genotypes (Curcuma longa L.) from sub-Himalayan terai region of India. Industrial Crops and Products, 150: 112401.

Quan, T. \& Fisher, G.J. 2015. Role of age-associated alterations of the dermal extracellular matrix microenvironment in human skin aging: a minireview. Gerontology, 61(51): 427-434.

Ramamurthy, S., Kumarappan, C., Dharmalingam, S.R. \& Sangeh, J.K. 2014. Phytochemical, pharmacological and toxicological properties of Ficus deltoidea: a review of a recent research. Annual Research \& Review in Biology, 14(4): 2357-2371.

Roslan, N.Z.I., Ghani, S.M.A., Yusof, N.B. \& Aziz, A.A. 2017. Liposome as transdermal carrier for Labisia pumila and Ficus deltoidea water extracts. Jurnal Teknologi, 79(7): 116-166

Shahrim, Z., Baharuddin, P., Yahya, N.A., Muhammad, H., Bakar, R.A. \& Ismail, Z. 2006. The in vivo rodent micronucleus assay of Kacip Fatimah (Labisia pumila) extract. Tropical Biomedicine, 23(2): 214-219.

Siti, Z., Tahir, A., Farah, A.I., Fazlin, S.A., Sondi, S., Azman, A., Maimunah, A., Haniza, M., Haslinda, M.S. \& Zulkarnain, A. 2009. Use of traditional and complementary medicine in Malaysia: a baseline study. Complementary Therapies in Medicine, 17(5-6): 292-299.

Soib, H.H., Yaakob, H., Sarmidi, M.R. \& Rosdi, M.N.M. 2019. Fractionation of aqueous extract of Ficus deltoidea var. Kunstleri's leaves using solid phase extraction method for anticancer activity on du145 cell line. Malaysian Journal of Analytical Sciences, 23(3): 534-547.

Takasao, N., Tsuji-Naito, K., Ishikura, S., Tamura, A. \& Akagawa, M. 2012. Cinnamon extract promotes type I collagen biosynthesis via activation of IGF-I signaling in human dermal fibroblasts. Journal of Agricultural and Food Chemistry, 60(5): 1193-1200.

Tamfu, A.N., Ceylan, O., Kucukaydin, S. \& Duru, M.E. 2020. HPLC-DAD phenolic profiles, antibiofilm, anti-quorum sensing and enzyme inhibitory potentials of Camellia sinensis (L.) O. Kuntze and Curcuma longa L. LWT Food Science and Technology, 133: 110150.

Thongmuang, P. \& Sudjaroen, Y. The Tyrosinase and Cyclooxygenase Inhibitory Activities and Cytotoxicity Screening of Tamarindus indica Seeds. International Journal of Agricultural and Biosystems Engineering, 7(1): 11-13.

Tobin, D.J. 2017. Introduction to skin aging. Journal of Tissue Viability, 26(1): 37-46. 
Vallianou, N.G., Evangelopoulos, A., Schizas, N. \& Kazazis, C. 2015. Potential anticancer properties and mechanisms of action of curcumin. Anticancer Research, 35(2): 645-651.

Wang, Y.H., Avula, B., Nanayakkara, N.D., Zhao, J. \& Khan, I.A. 2013. Cassia cinnamon as a source of coumarin in cinnamon-flavored food and food supplements in the United States. Journal of Agricultural and Food Chemistry, 61(18): 44704476.

World Health Organization 2000. General guidelines for methodologies on research and evaluation of traditional medicine. World Health Organization. World Health Organization 2015. World Report on Ageing and Health. World Health Organization.
You, J., Roh, K.B., Li, Z., Liu, G., Tang, J., Shin, S., Park, D. \& Jung, E. 2015. The antiaging properties of Andrographis paniculata by activation epidermal cell stemness. Molecules, 20(9): 17557-17569.

Zakaria, M.H. 2015. Review of policies and issues in the Malaysian herbal industry. FFTC Agricultural Policy Articles.

Zakaria, M.H. 2016. Development of Herbal Selection Criteria Model For Investment and Commercialization Decision. 
